\title{
EFFECT OF CLIMATE CHANGE ON GROUNDWATER AND SALTS STORAGE IN EL SHEIKH ZUWAID-RAFAH, NORTH SINAI, EGYPT
}

El-Malky, M. G. ${ }^{(1)}$; Sakr, S. A. ${ }^{(2)}$ and Dahabiyeh, Mona, H. ${ }^{(3)}$

1) Department of Environmental Basic Science, Institute of Environmental Studies and Research, Ain Shams University. 2) The Groundwater Sector in Ministry of Water Resources and Irrigation. 3) Water Authority of Jordan

\begin{abstract}
Identifying and quantifying future climate impacts on water resources has major economic and societal implications, rendering such studies extremely important for water planners. In this research, we integrate the outputs of the general global models GDFL-ESM2M (the suitable one of the three studied models; CNRM-CM5, GFDL-ESM2M and EC-EARTH) downscaled by regional climate model (RCA4) under representative concentration pathways RCPs scenarios 8.5, into two hydrological models to provide approximations of climate change impacts on water quantity and quality in El Sheikh ZuwaidRafah quaternary aquifer system which is the main source of water in the area. The projected changes of the rising scenario between the periods 19802005 and 2050-2075 from the three studied GCMs predicted an increase in the mean of July temperature between 4.2 - $4.8 \mathrm{~K}$ (kelvin degree), whereas January temperature was estimated to increase between 1.8 - $5.4 \mathrm{~K}$ (kelvin degree). The cumulative annual precipitation was estimated to decrease by a range varied between $30 \%$ to $51 \%$. A Simple Bias correction (SBC) technique was implemented to correct the simulated monthly precipitation series of RCA4 (GDFL-ESM2M) over Sinai Peninsula. A three dimensional finite difference flow model (Processing MODFLOW -PM5), and the implemented solute transport model (MT3D) were used to predict the groundwater and the total dissolved solids storage. Results from running the raising scenario RCP 8.5 estimated that by the hydrological year 2074 groundwater recharge would be decreased by $2.73 \mathrm{M} . \mathrm{m}^{3}$, leading with the
\end{abstract}


yearly exploitation to decrease groundwater storage to $11.83 \mathrm{M} . \mathrm{m}^{3}$ and decrease in dissolve salt storage $33.1 \mathrm{M}$. Kg.

Keywords: Global Climate Models; Regional Climate Model; Bias Correction; Groundwater Flow Model; Salt Transport Model

\section{INTRODUCTION}

Groundwater is the main resource of water in Sheikh Zuwaid-Rafah area in North Sinai Peninsula. The unconfined to semi confined quaternary aquifers that forms the groundwater system and extends on the Mediterranean coastal plain, is vulnerable to many non-climate stresses such as overpumping, pollution sources and sea water encroachment (El-Tablawi, 1997; El Alfy, 2003). In the Forth Assessment Report of the Intergovernmental Panel on Climate Change (IPCC, 2007), Mediterranean region were considered to be a 'hot spot' for climate change, it experienced an uneven increase in surface air temperature ranging from $0.2^{\circ} \mathrm{C}$ to $2.0^{\circ} \mathrm{C}$ that occurred from 1970 to 2004. This encouraged farther investigations to project significant impacts on both precipitation and land surface water availability, yet little is known about how groundwater will respond to climate change coupled with human activities (Holman, 2006; Bovolo et al., 2009). Altering precipitation in Sheikh Zuwaid-Rafah area can affect the renewable portion of groundwater leading to large scale of instability which is likely to exacerbate vulnerability. This paper aims to quantify the future potential effects of climate change on groundwater storage and salt transfer of the study region for the twenty first century.

The methodology usually followed to assess the hydrological consequences of climate change basically consists of a three-step process (Xu 
et al., 2005): (1) the development and use of general circulation models (GCMs) to provide future global climate scenarios under the effect of increasing greenhouse gases, (2) the development and use of downscaling techniques for "downscaling" the GCM output to the scales compatible with hydrological models, and (3) the development and use of hydrological models to simulate the effects of climate change on hydrological regimes at various scales.

Recently, the Coordinated Regional Climate Downscaling Experiment (CORDEX) program, initiated by the World Climate Research Program, provided the opportunity for generating high resolution regional climate projections, which can be used to assess the future impacts of climate change at regional scales (CORDEX, Giorgi et al. 2009). Six downscaling simulations at 0.44 degree resolution by regional climate model RCA4; RCA4 is a new version of Rossby Center regional atmospheric model RCA which is originally based on the numerical weather prediction model HIRLAM (Undén et al., 2002), of three GCMs; CNRM-CM5 (Voldoire et al., 2012), GFDL-ESM2M (Dunne et al., 2012), and EC-EARTH (Hazeleger et al., 2011), under two representative concentration pathways RCP 8.5 have been published via earth system grid federation (ESGF). The Representative Concentration Pathways (RCP) is the latest generation of scenarios that provide input to climate models. The word "representative" signifies that each RCP provides only one of many possible scenarios that would lead to the specific radiative forcing pathway. Radiative forcing is the difference in the balance of energy that enters the atmosphere and the amount that is returned to space compared to the pre-industrial situation. RCP 8.5 was developed by 
the International Institute for Applied System Analysis in Austria. This future is consistent with increasing greenhouse gas emissions that lead to high greenhouse gas concentrations over time, increased use of croplands and grassland which is driven by an increase in population, a world population of 12 billion by 2100 , lower rate of technology development, heavy reliance on fossil fuels, high energy intensity, and no implementation of climate policies

Assessing Groundwater storage in responses of the simulated climate change scenarios is based on hydraulic flow model that was constructed for El Sheik Zuwiyed - Rafah region to simulate the complex of the quaternary water bearing formations by (ACSAD \& DRC, 1998). The model is based on mathematical modeling technique applying three dimensional finite elements called processing MODFLOW (version 5) for WINDOWS (Chiang \& Kinzelbach, 1998). It was constructed on an area of about $176 \mathrm{~km}^{2}$ considering groundwater aquifers hydraulically connected as one hydraulic complex of multi-layered aquifers. Precipitation is considered as a direct source of recharge, so recharge was estimated to be 19.13 million cubic meters per year based on ten year average from 1985 to 1995 which ranged between 200-300 mm/year. Exploitation of groundwater aquifer was pumped out from 247 wells discharging about 23.97 million cubic meters per year. The model was calibrated; for transient state, finding that hydraulic conductivity coefficients range from less than 20 to more than $50 \mathrm{~m} /$ day while diffusivity coefficient varies from less than $50 \times 10^{3} \mathrm{~m}^{2} /$ day to more than $300 \times 10^{3} \mathrm{~m}^{2} /$ day from north and northeastern to south and southeastern direction of the studied area. 
The approach for assessing mass transport of total dissolved solids is based on El Tablawi (2010) designed salts transport model of El Sheikh Zuwaid-Rafah region. The model was carried out by using MT3D program that is governed by parabolic partial differential equation for transient state and linked with MODFLOW program (Chiang \& Kinzelback, 1998). Salts distribution was defined based on the calibrated results of ACSAD\&DRC hydraulic flow model. The interaction between the two models was applied by multi sweep method of alternative consequent runs for hydraulic parameters and salts content. Longitudinal dispersivity was estimated $76.8 \mathrm{~m}$ therefore transverse dispersivity was estimated to be $7.68 \mathrm{~m}$ and $0.768 \mathrm{~m}$ in horizontal and vertical directions respectively. The effective molecular diffusion is calculated as $6.048 \times 10^{-5} \mathrm{~m}^{2} /$ day. The model is calibrated and the adjusted value of effective porosity varied from more than 0.25 in the southern direction to less than 0.15 in the northern direction.

In order to predict the effect of climate change on groundwater storage and salt transport, monthly simulated precipitation outputs from regional climate model RCA4 driven by three general circulation models starting from 1980 till 2005, have been verified to select the best fitting simulation. The selected simulation was corrected and used as an input in two previously constructed models in the Sheikh Zuwaid-Rafah area; a hydraulic flow model by (ACSAD \&DRC, 1998) and salts transport model by (El Tablawi, 2010) with complete interaction between them. 
El Sheikh Zuwaid-Rafah area is located in the north eastern part of Sinai Peninsula and covers about $167 \mathrm{Km}^{2}$. The area extends between latitudes $31.15^{\circ}-31.32^{\circ}$ $\mathrm{N}$ and longitudes $34.04^{\circ}-34.25^{\circ}$ E. It's bordered in the north by the Mediterranean Sea, to the east by the international border between Egypt and Palestine, and in the south by central Sinai Peninsula (ACSAD \& DRC, 1998).

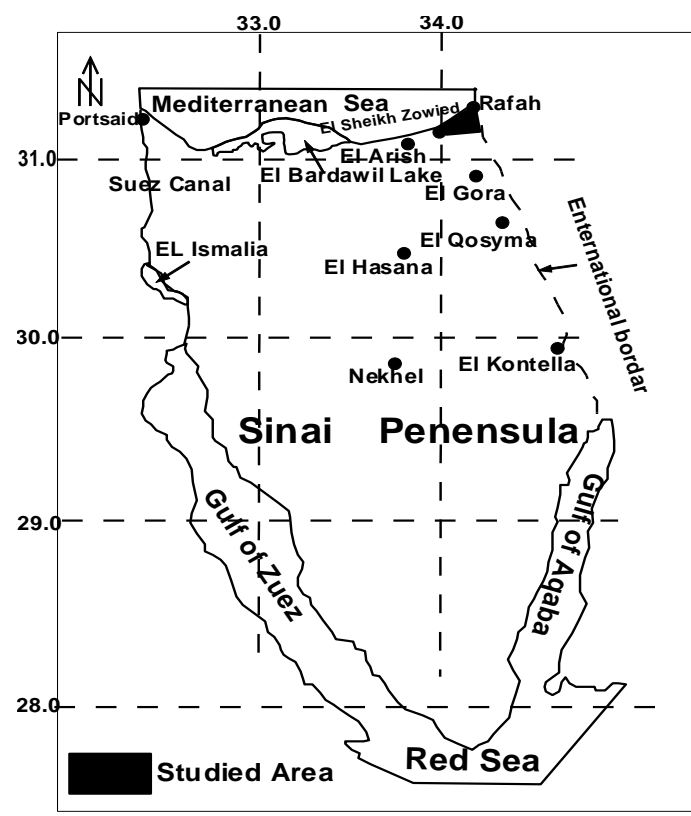

Figure (1) Location map of the studied area (after ASCAD \& DRC, 1998)

Water in El Sheikh Zuwaid - Rafah Quaternary aquifers flow under the effect of the gravity force from southeast to northwest down gradient until it reaches the Mediterranean Sea. Such movement is remarkably affected by the local groundwater exploitation and the direct recharge from rainfall (ACSAD \& DRC, 1998).

\section{METHODOLOGY}

For the aim of this study; which is studying the impact of climate change on groundwater, two main steps were followed; first the use of downscaled global circulation models GCM by nested regional climate model RCM to the scales compatible with hydrological models techniques, second the use of 
hydraulic flow and salt transport model to simulate the impacts of climate change on groundwater quantity and quality.

- Downloading output data of CORDEX MENA simulations had been published via earth system grid federation (ESGF). For this research the downloaded data are of Middle East North Africa domain, the regional model is RCA4; RCA is originally based on the numerical weather prediction model HIRLAM (Undén et al., 2002), the driving models are CNRM-CM5 (Voldoire et al., 2012), GFDL-ESM2M (Dunne et al., 2012), and EC-EARTH (Hazeleger et al., 2011), the variables are surface air temperature and precipitation, the used experiments are evaluation, historical, RCP 8.5 , with resolution $0.44^{\circ}(50 \mathrm{~km})$, and monthly time frequency (1980 - 2100).

- Python program had been used to read the NetCDF files, then grid points that cover all Sinai Peninsula were extracted.

- Verification; CORDEXs evaluated the performance of the regional climate model RCA4 over the MENA region, based on comparing results from RCA4 forced with ERA-Interim ( abbreviated as ERAINT) with ERAInterim itself. ERAINT is a global atmospheric reanalysis produced by the European Centre for Medium-Range Weather Forecasts (ECMWF) (Dee, et al. 2011). Therefore, three sources of gridded surface meteorological data of each variable (referred to it in this research as observed datasets); which had been created on global and regional scale with different resolution to overcome the limitations of high quality and short-term interrupted measurement, were used to verify both of ERAINT and RCA4ERAINT. Since there were differences between the three sources, an 
averaged grid datasets was established from previous used observed datasets to be used. Verification has been done statistically by comparing the central tendency, spread, cumulative frequency distribution, correlation and trend for the historical period $1980-2005$ of the previous datasets. The observed data sets that have been used for precipitation and temperature are as follow:

Climate Research Unit CRU (Harris et al., 2014),

$>$ European land daily high resolution gridded data set E-OBS (Haylock et al., 2008), and

Precipitation Reconstruction over Land PREC/L of Climate Prediction Center (Chen et al., 2002),

University of Delaware UDel (Willmott and Matsuura, 1995)

- Bias correction: although RCMs are able to simulate local climate at finer resolutions, outputs from RCMs cannot be used as a direct input data for hydrological models due to their systematic errors caused by imperfect conceptualization, discretization and spatial averaging within grid cells (Christensen et al., 2008). Simple Bias correction (SBC) technique has been used for precipitation scaling which is process that based on the use of a multiplicative factor (see equation (1)). This factor is assumed to remain unvaried even for future conditions (Graham et al., 2007). To preserve the statistical attributes, correction was applied on each month separately then corrected months were grouped to form the precipitation time series. Corrections were done referring to the averaged observed datasets. Thirty five grid points covered the study area with resolution 
$0.44^{\circ}$ (approximates $50 \mathrm{Km}^{2}$ ); each of them has been corrected with their six ratios that represents the wet season months giving 210 ratio for the model experiment.

$$
\boldsymbol{P}_{\text {corr }}^{*}(t)=\boldsymbol{P}_{\text {sim }}(\boldsymbol{t}) \cdot\left[\frac{\mu\left(\boldsymbol{P}_{\text {obs }}(t)\right)}{\mu\left(\boldsymbol{P}_{\text {sim }}(t)\right)}\right]
$$

where:

$$
\begin{aligned}
& P_{\text {corr }}^{*}(t)=\text { corrected simulated precipitation values at time } t \\
& P_{\text {sim }}(t)=\text { simulated precipitation values at time } t \\
& \mu\left(P_{\text {obs }}(t)\right)=\text { mean of observed precipitation } \\
& \mu\left(P_{\text {sim }}(t)\right)=\text { mean of simulated precipitation }
\end{aligned}
$$

- Long term means: the selected studied period of CORDEX simulation is extended from 1980 to the end of the $21^{\text {th }}$ century. It has been divided into five periods to compare the effects of changing precipitation on water and salt storage of the groundwater aquifers. The periods are 1980-1994, 19952009, 2010-2024, 2025-2049, and 2050-2074. In each period, precipitation means (of the wet season) have been calculated for all selected grid points that represent Sinai, creating new grid net to be used. 

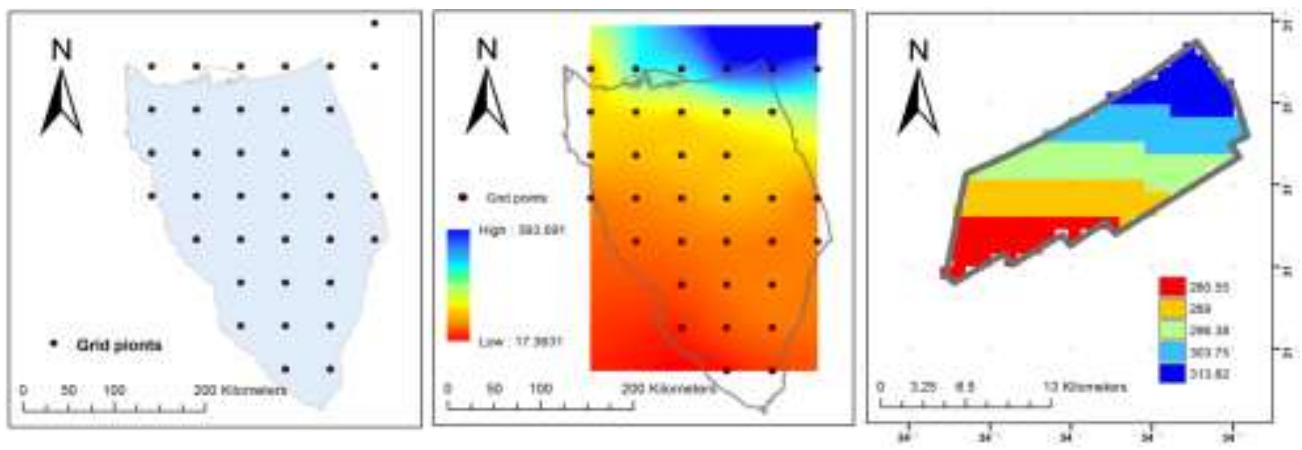

Figure (2): Steps of working with GIS tool; from right to left: plotting the

- Kriging interpolation: using geographical information system (GIS) an optimal estimation of a precipitation at the unmeasured locations based on regression against grids values of surrounding points, weighted according to spatial covariance values have been implemented.

- Extraction and classification: data of the study area was extracted from the constructed grid surface by kriging interpolation, and then it was classified into zonation which will be the input data for recharge in the MODFLOW model.

- The data for water and salt storage of El Sheikh Zuwaid-Rafah quaternary aquifer system; which include observed, experimental and the trend, as well as the verification of hydrological models using MODFLOW and MT3D (version 5) have been quoted from ACSAD \&DRC (1998) and El Tablawi (2010). 
- Running the hydraulic flow and salt transport models 78 times in multi sweep method of alternative consequent runs for hydraulic parameters and salts content of each experiment of the sixth simulation.

\section{RESULTS AND CONCLUSIONS}

\section{Statistical verification of RCA4:}

This part is concerned with viewing the effect of RCA4 forced by ERAINT compared with ERAINT itself from 1980-2005 at Rafah region although verification were implemented over all grid points of Sinai Peninsula . Table (1) summarizes the descriptive statistics of the temperature and precipitation. January and July series were selected to represent the temperature in winter and summer while precipitation was represented through total and January series. It is clear that RCA4 improved the temperature statistics with increasing the variability in both of January and July series while precipitation statistics did not show such improvement for example mean yearly precipitation was decreased by $60 \%$ from ERAINT which itself is less than the average of observed data by $56 \%$. 
J. Environ. Sci.

Institute of Environmental Studies and Research - Ain Shams University

Table (1): Descriptive statistics of the average of observed, ERAINT, and RCA4-ERAINT from 1980-2005 at Rafah, Egypt

\begin{tabular}{|c|c|c|c|c|}
\hline \multicolumn{5}{|c|}{ Temperature statistics } \\
\hline month & Statistic & Avg & ERAINT & ERAINT_RCA4 \\
\hline \multirow{4}{*}{ January } & Minimum & 283.35 & 286.33 & 277.12 \\
\hline & Maximum & 288.55 & 292.40 & 293.69 \\
\hline & Mean & 286.17 & 289.30 & 284.08 \\
\hline & Standard deviation (n-1) & 1.43 & 1.63 & 2.83 \\
\hline \multirow{4}{*}{ July } & Minimum & 298.65 & 305.11 & 296.84 \\
\hline & Maximum & 302.15 & 308.17 & 305.38 \\
\hline & Mean & 300.07 & 306.35 & 299.93 \\
\hline & Standard deviation $(n-1)$ & 0.98 & 0.90 & 1.33 \\
\hline \multicolumn{5}{|c|}{\begin{tabular}{|l} 
Precipitation statistics \\
\end{tabular}} \\
\hline \multirow{4}{*}{$\begin{array}{c}\text { yearly } \\
\text { (total } \\
\text { precipitation) }\end{array}$} & Minimum & 129.90 & 59.95 & 39.71 \\
\hline & Maximum & 431.33 & 190.22 & 51.33 \\
\hline & Mean & 271.71 & 118.07 & 46.16 \\
\hline & Variation coefficient & 0.29 & 0.30 & 0.10 \\
\hline \multirow{4}{*}{ January } & Minimum & 20.83 & 3.63 & 0.00 \\
\hline & Maximum & 119.53 & 46.77 & 16.48 \\
\hline & Mean & 66.34 & 21.64 & 8.09 \\
\hline & Variation coefficient & 0.42 & 0.50 & 0.86 \\
\hline
\end{tabular}

Trends of monthly, January and July series have been examined using statistics for goodness of fitting; $\mathrm{R}^{2}$ and adjusted $\mathrm{R}^{2}$, of the liner regression model at a 95\% confident interval. Only July air temperature series showed a significant increase trend with 0.098 and $0.088 \mathrm{~K} / \mathrm{y}$ (Kelvin per year) for averaged of observed and ERAINT respectively at Rafah region. RCA4 did not maintain the general trend of July see figure (3). 

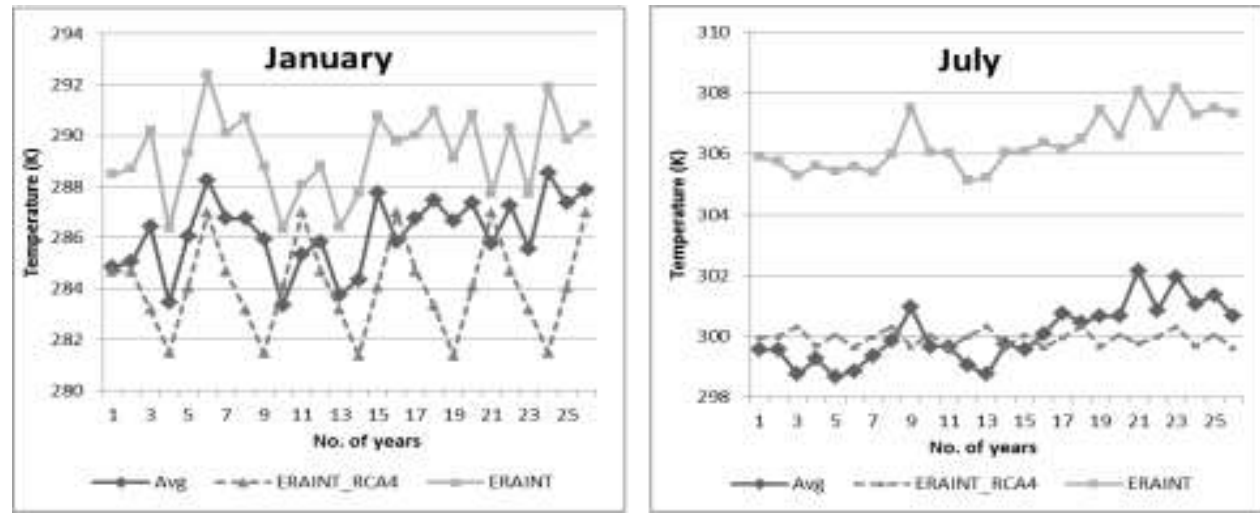

Figure (3): Surface air temperature at Rafah region, on the left January

Table (2): Goodness of fit statistics for air temperature

\begin{tabular}{|c|c|c|c|}
\hline \multicolumn{4}{|c|}{ Monthly temperature series } \\
\hline & Avg & ERAINT & ERAINT_RCA4 \\
\hline $\mathbf{R}^{2}$ & 0.0154 & 0.0049 & 0.0011 \\
\hline Adjusted $\mathbf{R}^{2}$ & 0.0123 & 0.0017 & -0.0021 \\
\hline F & 4.8625 & 1.5421 & 0.3547 \\
\hline $\mathbf{P r}>\mathbf{F}$ & 0.0282 & 0.2152 & 0.5519 \\
\hline \multicolumn{4}{|c|}{ January temperature series } \\
\hline & Avg & ERAINT & ERAINT_RCA4 \\
\hline $\mathbf{R}^{2}$ & 0.2045 & 0.0468 & 0.0032 \\
\hline Adjusted $\mathbf{R}^{2}$ & 0.1714 & 0.0071 & -0.0384 \\
\hline F & 6.1714 & 1.1792 & 0.0764 \\
\hline $\mathbf{P r}>\mathbf{F}$ & 0.0204 & 0.2883 & 0.7846 \\
\hline \multicolumn{4}{|c|}{ July temperature series } \\
\hline & Avg & ERAINT & ERAINT_RCA4 \\
\hline $\mathbf{R}^{2}$ & 0.5942 & 0.5604 & 0.0081 \\
\hline Adjusted $\mathbf{R}^{2}$ & 0.5773 & 0.5420 & -0.0332 \\
\hline F & 35.1436 & 30.5906 & 0.1963 \\
\hline Pr $>F$ & $<0.0001$ & $<0.0001$ & 0.6617 \\
\hline
\end{tabular}


Since precipitation does not follow a normal distribution, trend of the total precipitation series has been tested using Mann-Kendall trend test. Results showed that there is a significant trend (trend $\neq 0$ ) in the ERAINT while RCA4-ERAINT showed no significant trend (trend $=0$ ) see figure 4.

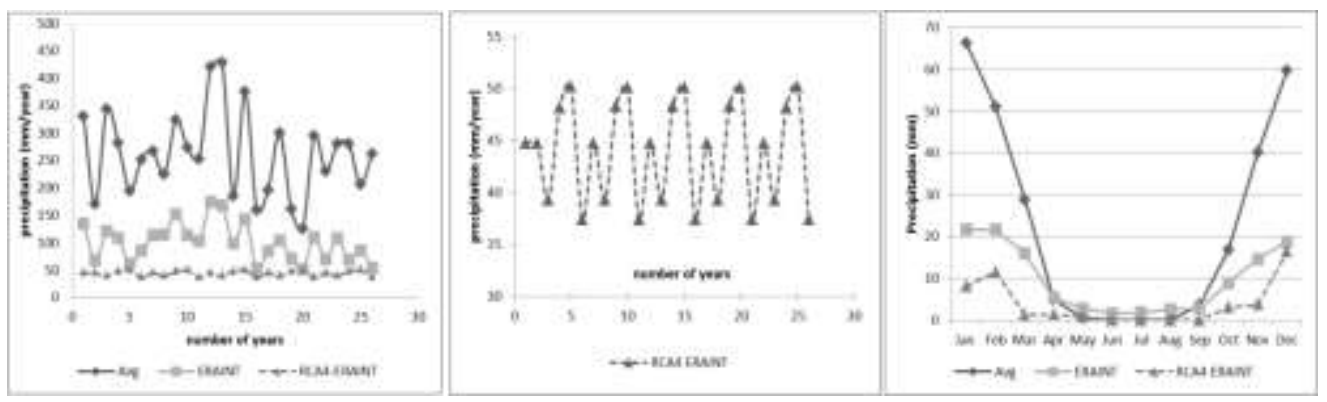

Figure (4): The total precipitation series of the average of observed,

RCA4 kept on the same strong significant correlation (Pearson) in temperature 0.93 at a significance level alpha $=0.05$. As for precipitation a significant correlation (Pearson) was tested between RCA4-ERAINT and ERAINT itself in the monthly series 0.59 at a significance level alpha=0.05.

Table (3): Pearson Correlation Coefficients

\begin{tabular}{|c|c|c|c|}
\hline \multicolumn{4}{|c|}{ Temperature monthly series } \\
\hline & Avg & ERAINT & RCA4 ERAINT \\
\hline Avg & $\mathbf{1}$ & 0.9815 & 0.9321 \\
\hline ERAINT & $\mathbf{0 . 9 8 1 5}$ & $\mathbf{1}$ & 0.9499 \\
\hline \multicolumn{4}{|c|}{ Precipitation monthly series } \\
\hline Avg & $\mathbf{1}$ & $\mathbf{0 . 8 5 2 5}$ & 0.5988 \\
\hline ERAINT & $\mathbf{0 . 8 5 2 5}$ & $\mathbf{1}$ & 0.4940 \\
\hline
\end{tabular}

Values in bold are different from 0 with a significance level alnha $=0.05$ 
As for the effect of RCA4 on the data distribution; January and July temperature series were selected to reflect summer and winter seasons. Using a non-parametric test (Kolmogorov-Smirnov test) January series were found to distribute normally with a significant level as well as it was in ERAINT and averaged of observed. While for July series, they did not match any distribution significantly except for specified location such as Ras Sudr and Rafah which were normally distributed. The precipitation distribution; averaged and ERAINT yearly cumulative precipitation series (total) have been found to follow a Weibull (3) distribution, at a significance level alpha $=0.1$. While neither the yearly nor monthly series of RCA-ERAINT had a significant data distribution at alpha equal 0.1,0.2 and 0.3.

Table (4): The probability value of temperature distribution nonparametric Kolmogorov-Smirnov test at alpha $=0.1$ of

\begin{tabular}{crr}
\hline Location & January & \multicolumn{2}{c}{ July } \\
\hline st. Catherin & $\mathbf{0 . 7 7 3 4}$ & 0.0016 \\
Ras Sudr & $\mathbf{0 . 3 4 5 6}$ & $\mathbf{0 . 2 6 6 3}$ \\
Nakhl & $\mathbf{0 . 5 6 3 8}$ & 0.0289 \\
Maghara & $\mathbf{0 . 1 1 2 2}$ & 0.0486 \\
Rafah & $\mathbf{0 . 3 3 8 5}$ & $\mathbf{0 . 2 7 8 5}$ \\
\hline
\end{tabular}

Studying precipitation patterns in each month series, it have been concluded that RCA4 created a pattern that repeat itself every five years at all months, generally the pattern based on the highest and lowest peaks in the ERAINT 
J. Environ. Sci.

Institute of Environmental Studies and Research - Ain Shams University

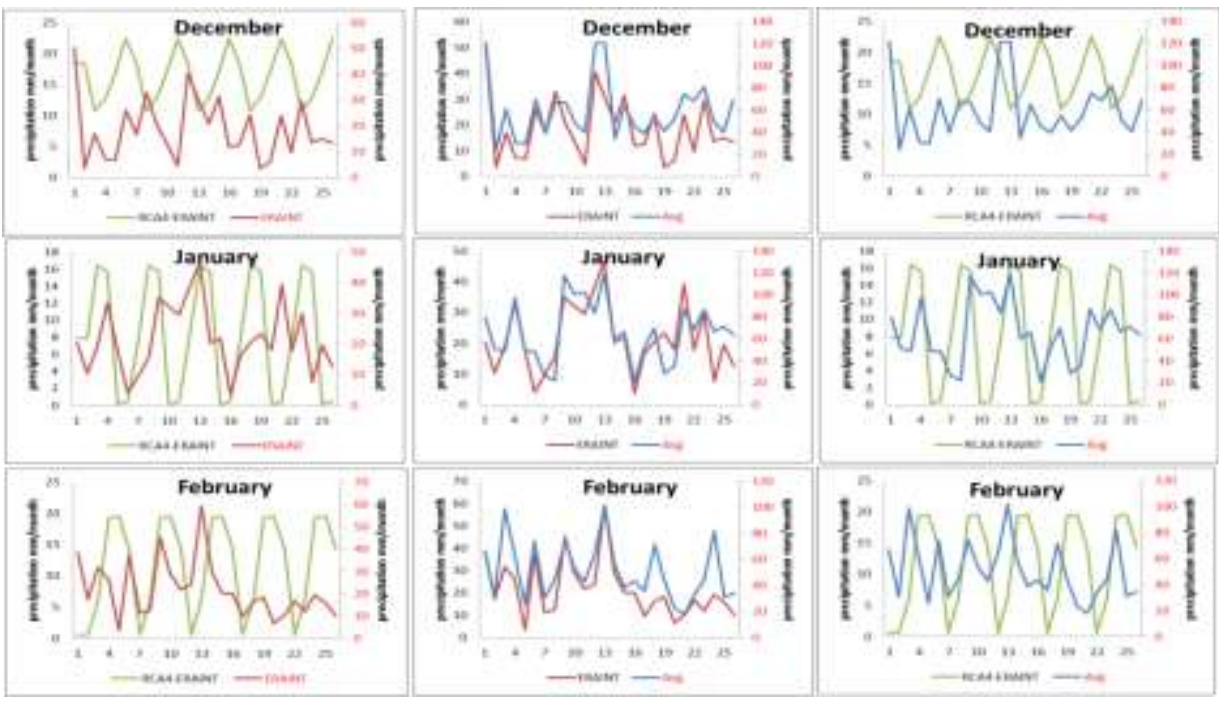

Figure (5): Monthly precipitation series of the average of observed,

2.Climate projections: Maps in figure (6) show the expected changes in monthly temperature (January and July) and annual precipitation estimated by RCA4 (GDFL-ESM2M), RCA4 (CNRM-CM5) and RCA4 (ECEARTH) between the periods 1980-2005 and 2050-2075. Data has been interpolated then classified. 

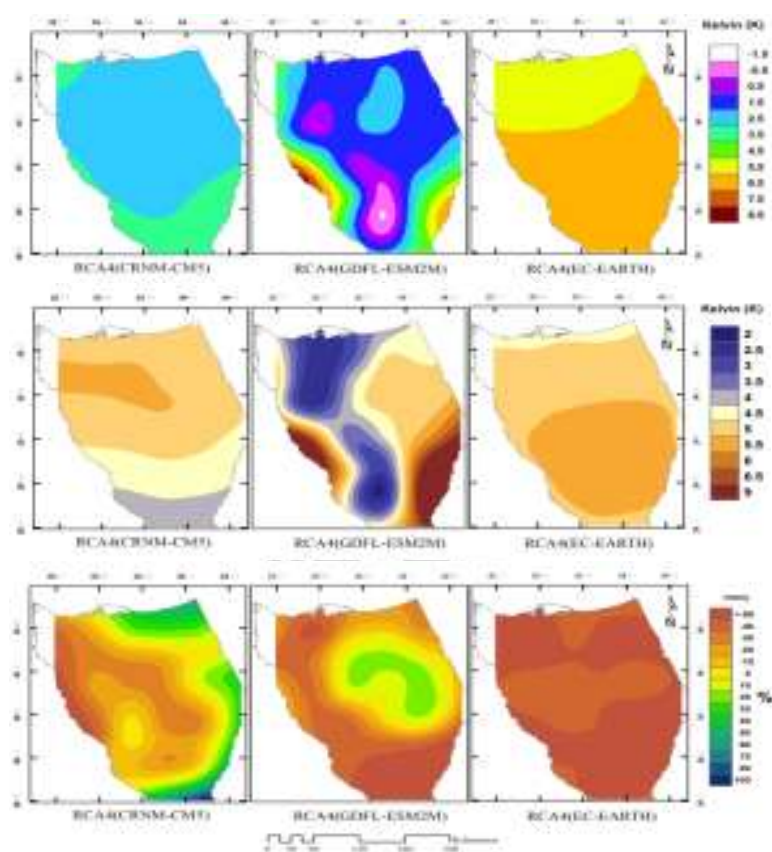

Figure (6): Expected changes of RCP 8.5 scenario in January ([Kelvin], 1st row), July ([kelvin], 2nd row) and cumulative annual precipitation ([\%], 3rd row) computed of the three GCMs (2050-2075 vs. 1980-2005).

Results from RCP8.5 scenario estimated a mean increase in the July temperature between 4.2 - 4.8 kelvin degrees, whereas January temperature estimated to increase between 1.8 - 5.4 kelvin degrees. The cumulative annual precipitation was projected to decrease by a range varied of $30-51 \%$.

3. The stabile GCM for Sinai Peninsula: Mean squared error (MSE) and Root mean squared error (RMSE) are used to measure of the quality of the downscaled historical data (1980-2005) of the three GCMs. As for of air temperature, RCA4-CNRM-CM5 had the least MSE in almost all regions; with exception in the southern mountain area, while for precipitation the least RMSE differ with the location. In Rafah region, RCA4-GDFLVol. 38, No.2, Jun. 2017 
J. Environ. Sci.

Institute of Environmental Studies and Research - Ain Shams University

ESM2M had the least deviation from the averaged of observed thus output

of this model was used as input in the hydraulic flow model

Table (5): Mean square error of the monthly simulated surface air temperature

\begin{tabular}{|c|c|c|c|c|}
\hline $\begin{array}{c}\text { Grid } \\
\text { Location }\end{array}$ & $\begin{array}{c}\text { Compared } \\
\text { to }\end{array}$ & $\begin{array}{c}\text { RCA4 } \\
\text { GFDL-ESM2M }\end{array}$ & $\begin{array}{c}\text { RCA4 } \\
\text { CNRM-CM5 }\end{array}$ & $\begin{array}{c}\text { RCA4 } \\
\text { EC-EARTH }\end{array}$ \\
\hline \multirow{3}{*}{ St.Catherin } & Avg & 6.45 & 8.75 & 8.14 \\
\hline & ERAINT & 135.24 & 138.24 & 146.84 \\
\hline & RCA4 ERAINT & 7.00 & 8.55 & 9.96 \\
\hline \multirow{3}{*}{ Ras Sudr } & Avg & 11.11 & 9.67 & 14.01 \\
\hline & ERAINT & 70.72 & 65.48 & 81.71 \\
\hline & RCA4 ERAINT & 6.27 & 5.78 & 9.30 \\
\hline \multirow{3}{*}{ Nakhl } & Avg & 9.65 & 8.64 & 13.10 \\
\hline & ERAINT & 74.22 & 71.88 & 87.62 \\
\hline & RCA4 ERAINT & 7.16 & 6.84 & 9.82 \\
\hline \multirow{3}{*}{ Maghara } & Avg & 8.70 & 8.03 & 12.82 \\
\hline & ERAINT & 79.67 & 79.46 & 96.35 \\
\hline & RCA4 ERAINT & 4.89 & 4.10 & 6.66 \\
\hline \multirow{3}{*}{ Rafah } & Avg & 5.40 & 5.15 & 7.75 \\
\hline & ERAINT & 43.96 & 44.80 & 56.96 \\
\hline & RCA4 ERAINT & 4.58 & 4.17 & 6.24 \\
\hline
\end{tabular}

Table (6): Root mean square error of the monthly simulated precipitation

\begin{tabular}{|c|c|c|c|c|}
\hline $\begin{array}{c}\text { Grid } \\
\text { Location }\end{array}$ & $\begin{array}{c}\text { Compared } \\
\text { to }\end{array}$ & $\begin{array}{c}\text { RCA4 } \\
\text { GFDL-ESM2M }\end{array}$ & $\begin{array}{c}\text { RCA4 } \\
\text { CNRM-CM5 }\end{array}$ & $\begin{array}{c}\text { RCA4 } \\
\text { EC-EARTH }\end{array}$ \\
\hline \multirow{3}{*}{ St. Catherin } & Avg & 17.94 & 50.63 & 25.05 \\
\hline & ERAINT & 18.34 & 51.56 & 26.30 \\
\hline & RCA4 ERAINT & 15.34 & 50.48 & 24.76 \\
\hline \multirow{3}{*}{ Ras Sudr } & Avg & 7.28 & 7.32 & 7.24 \\
\hline & ERAINT & 2.75 & 3.03 & 2.85 \\
\hline & RCA4 ERAINT & 1.59 & 2.27 & 1.97 \\
\hline \multirow{3}{*}{ Nakhl } & Avg & 11.72 & 12.04 & 11.27 \\
\hline & ERAINT & 5.01 & 5.81 & 4.67 \\
\hline & RCA4 ERAINT & 3.72 & 4.89 & 3.68 \\
\hline \multirow{3}{*}{ Maghara } & Avg & 13.11 & 16.77 & 12.79 \\
\hline & ERAINT & 8.62 & 13.89 & 9.25 \\
\hline & RCA4 ERAINT & 8.44 & 14.11 & 9.34 \\
\hline \multirow{3}{*}{ Rafah } & Avg & 29.71 & 36.24 & 29.86 \\
\hline & ERAINT & 13.41 & 21.48 & 13.91 \\
\hline & RCA4 ERAINT & 12.77 & 20.77 & 12.75 \\
\hline
\end{tabular}


4. Bias Correction: Bias had been detected, therefore correction process is necessity. Corrections had been done to the precipitation data from RCA4GDFL-ESM2M referring to the averaged of observed datasets. Ratios of the wet months (October to March) of the thirty five grid points that cover Sinai Peninsula with resolution $0.44^{\circ}$ (approximates $50 \mathrm{Km}^{2}$ ) have been calculated, table 7 views some ratios of grid points near Sheikh ZuwaidRafah region.

Table (7): Bias correction ratios for grid points near Sheikh Zuwaid-Rafah, Egypt

\begin{tabular}{|c|c|c|c|r|r|r|r|}
\hline lat & lon & \multicolumn{1}{c|}{ Jan } & Feb & Mar & \multicolumn{1}{c|}{ Oct } & \multicolumn{1}{c|}{ Nov } & \multicolumn{1}{c|}{ Dec } \\
\hline 30.8 & 34.32 & 8.86 & 2.98 & 5.9 & 4.24 & 1.3 & 7.6 \\
\hline 31.24 & 32.56 & 1.08 & 2.03 & 4.85 & 0.76 & 0.33 & 1.6 \\
\hline 31.24 & 33 & 2.41 & 3.67 & 11.1 & 2.7 & 1.1 & 4.79 \\
\hline 31.24 & 33.44 & 4.95 & 3.93 & 2.78 & 1.25 & 3.8 & 3.95 \\
\hline 31.24 & 33.88 & 3.34 & 3.72 & 6.33 & 5.4 & 1.41 & 6.2 \\
\hline 31.24 & 34.32 & 3.18 & 3.09 & 6.43 & 7.3 & 1.53 & 6.16 \\
\hline
\end{tabular}

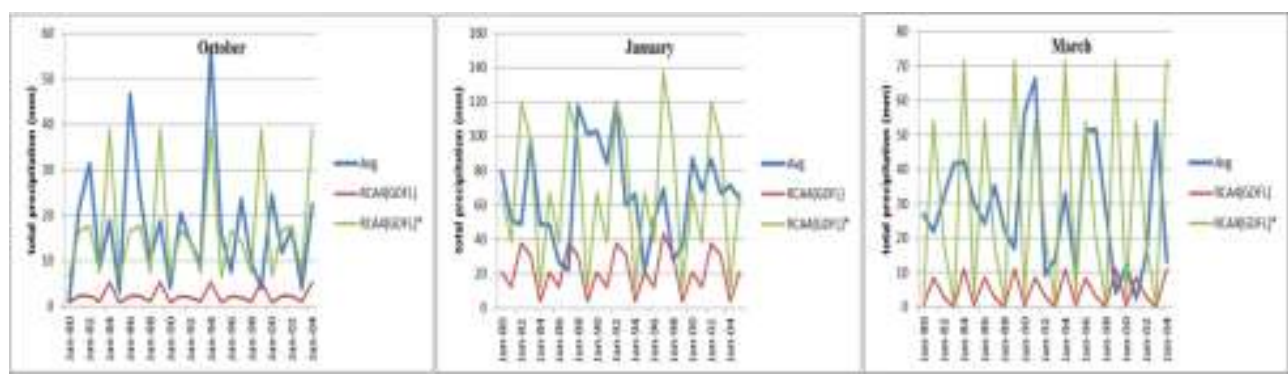

Figure (7) Monthly correction [green line] of grid cell $(31.24,34.32)$ comparing to the averaged of observed [blue line] and simulated of RCA4 (GDFL-ESM2M) [red line]

5. Water and salt budgets: Water and salt budget were calculated at the end of the five selected periods which are at 1996, 2010, 2024, 2049, and 2074. Differences between every two consecutive are studied to view expected 
variations over time. Results of the rising scenarios are summarized in table (9) where the negative sign refers to losing and the positive refers to gaining.

The simulated amount of precipitation (meter per day) of each zone for the five periods is summarized in table (8). These output data have been used as input in the hydraulic flow model to estimate the recharge amount. Generally recharge over the period of 1997 till 2024 have estimated to decrease by amount of 2.73 million cubic meters, then it fixed at 24 $\mathrm{Mm}^{3} /$ year.

Groundwater storage is estimated to decrease by 11.83 million cubic meters over 78 year. Variation of the groundwater storage has been changed as $-11.53,-0.082,-0.221$ and -0.0009 million cubic meters.

Dissolved salt storage was estimated was estimated to decrease by 33.1 million kilograms over 78 year. Dissolved salt storage has varied over the selected period as $-46.77,5.97,3.86$ and 3.81million kilograms.

Table (8): precipitation means zonation of RCA4-GFDL-ESM2M

\begin{tabular}{l|lllll} 
periods & Zone 1 & Zone 2 & Zone 3 & Zone 4 & Zone 5 \\
\hline $1980-1994$ & 0.00137 & 0.00143 & 0.00147 & 0.00150 & 0.00154 \\
$1995-2009$ & 0.00134 & 0.00139 & 0.00142 & 0.00145 & 0.00149 \\
$2010-2024$ & 0.00125 & 0.00129 & 0.00131 & 0.00133 & 0.00135 \\
$2025-2049$ & 0.00125 & 0.00128 & 0.00131 & 0.00133 & 0.00136 \\
$2050-2074$ & 0.00125 & 0.00128 & 0.00131 & 0.00133 & 0.00135
\end{tabular}


Table (9):Water and Salt balance accumulated variation over the 78 year

\begin{tabular}{|c|c|c|c|c|}
\hline \multicolumn{5}{|c|}{ Water balance cumulative variation } \\
\hline $\begin{array}{c}\text { comparied } \\
\text { Periods } \\
\end{array}$ & Constant Head & $\begin{array}{c}\text { Head Dependent } \\
\text { Boundary }\end{array}$ & $\begin{array}{c}\text { Groundwater } \\
\text { Recharge }\end{array}$ & $\begin{array}{c}\text { Groundwater } \\
\text { storage }\end{array}$ \\
\hline$(1996-1997)-(2009-2010)$ & -1.926 & -8.773 & -0.830 & -11.529 \\
\hline$(2009-2010)-(2023-2024)$ & -1.160 & -7.713 & -2.738 & -11.612 \\
\hline$(2023-2024)-(2048-2049)$ & -1.223 & -7.871 & -2.738 & -11.833 \\
\hline$(2048-2049)-(2073-2074)$ & -1.223 & -7.872 & -2.738 & -11.834 \\
\hline \multicolumn{5}{|c|}{ Salt balance cumulative variation } \\
\hline $\begin{array}{l}\text { comparied } \\
\text { Periods }\end{array}$ & $\begin{array}{c}\text { Constant } \\
\text { Concentration }\end{array}$ & $\begin{array}{c}\text { Dissolved Salts } \\
\text { Dependent Boundary }\end{array}$ & $\begin{array}{c}\text { Recharge of } \\
\text { Dissolved Salts }\end{array}$ & $\begin{array}{c}\text { Storage of } \\
\text { Dissolved Salts }\end{array}$ \\
\hline$(1996-1997)-(2009-2010)$ & -5.697 & -38.949 & -1.132 & -46.774 \\
\hline$(2009-2010)-(2023-2024)$ & -4.478 & -33.012 & -3.614 & -40.808 \\
\hline$(2023-2024)-(2048-2049)$ & -4.588 & -31.076 & -3.614 & -36.946 \\
\hline$(2048-2049)-(2073-2074)$ & -4.584 & -29.160 & -3.614 & -33.130 \\
\hline
\end{tabular}

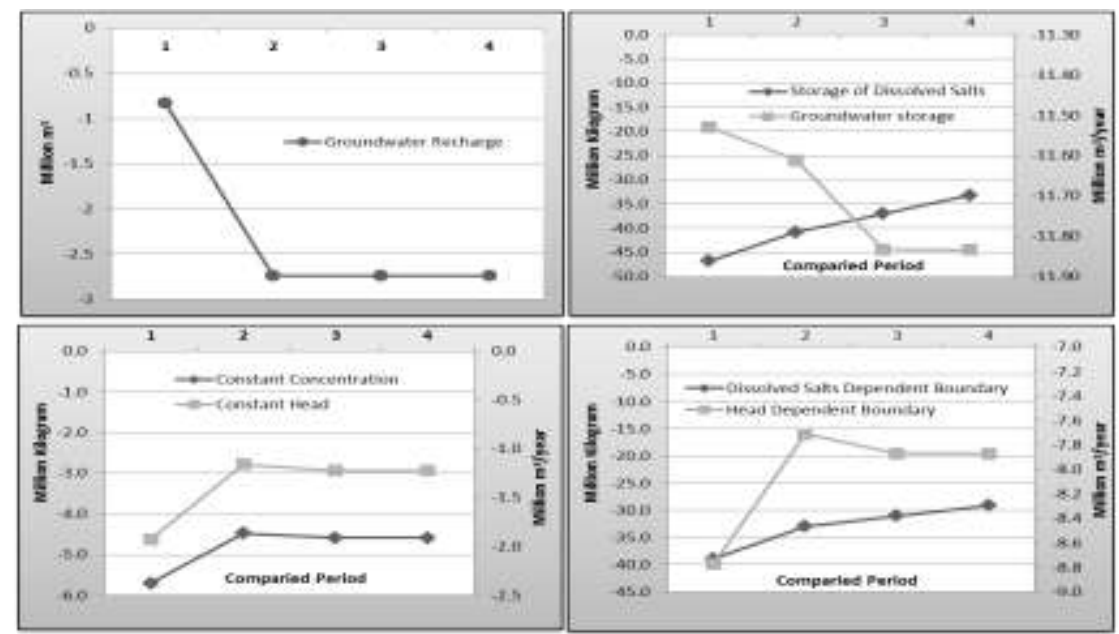

Figure (8): Variations over the four compared periods of: (a) recharge estimation (b) the groundwater and dissolved storage (c) constant head and concentration (d) head and dissolved salt 


\section{REFERENCES}

Bovolo, C.I.; Parkin, G. \& Sophocleous, M. (2009): Groundwater resources, climate and vulnerability, Environ. Res. Lett. 4 (3), 035001.

Chen, M.; Xie, P.; Janowiak, J. \& Arkin, P. (2002): Global land precipitation: A 50-yr monthly analysis based on gauge observations, J. Hydrometeorol., 3, 249-266.

Chiang, H.W. \& Kinzelbach, W. (1998): Processing MODFLOW, 3Dgroundwater modeling with PMWIN, a simulation system for modeling groundwater flow and pollution, ISBN 3-540-67744-S Springer - Verlag Berlin Heidelberg, New York.

Chiang, H.W. and Kinzelbach, W. (1998): Processing Modflow , 3DGroundwater Modeling With PMWIN, a Simulation System for Modeling Groundwater Flow and Pollution, ISBN 3-540-67744-S Springer - Verlag Berlin Heidelberg, New York.

Christensen, J.H., Boberg, F., Christensen, O.B., Lucas-Picher, P. (2008): On the need for bias correction of regional climate change projections of temperature and precipitation. Geophys. Res. Lett. 35 (L20709), 6.

Davied B. Vance, (2002): Transverse Dispersion as The Natural Driving Force, http/www. 2he4.net/natat4disp.htm.

Dee, D. P.; Uppala, S. M.; Simmons, A. J.; Berrisford, P.; Poli, P.; Kobayashi, S.; Andrae, U.; Balmaseda, M. A.; Balsamo, G.; Bauer, P.; Bechtold, P.; Beljaars, A. C. M.; van de Berg, L.; Bidlot, J.; Bormann, N.; Delsol, C.; Dragani, R.; Fuentes, M.; Geer, A. J.; Haimberger, L.; Healy, S. B.; Hersbach, H.; Hólm, E. V.; Isaksen, L.; Kållberg, P.; Köhler, M.; Matricardi, M.; McNally, A. P.; Monge-Sanz, B. M.; Morcrette, J.-J.; Park, B.-K.; Peubey, C.; de Rosnay, P.; Tavolato, C.; Thépaut, J.-N. \& Vitart, F. (2011), The ERA-Interim reanalysis: configuration and performance of the data assimilation system. Q.J.R. Meteorol. Soc., 137: 553-597. 
Dunne, John P.; John, Jasmin G.; Adcroft, Alistair J.; Griffies, Stephen M.; H allberg, Robert W.; Shevliakova, Elena; Stouffer, Ronald J.; Cook e, William; Dunne, Krista A.;Harrison, Matthew J.; Krasting, Joh n P.; Malyshev, Sergey L.; Milly, P. C. D.; Phillipps, Peter J.; Sen tman, Lori T.; Samuels, Bonita L.; Spelman, Michael J.; Winton, Michael;Wittenberg, Andrew T. \& Zadeh, Niki (2012), GFDL's ESM2 Global Coupled Climate-Carbon Earth System Models. Part I: Physical Formulation and Baseline Simulation Characteristics. J. Climate, 25, 6646-6665.

El Alfy, M. (2003): Environmental Impact of the Geo-morphological and Hydro-geological Aspects of Rafah area, North Sinai, Egypt. Ph.D. thesis. Mansoura University, Fac. Sci.

El Tablawi, E.M.S. (1997), Sea Water Intrusion in The Coastal Aquifer Between Rafah and Sheikh Zowied (North Sinai) and its Impact on the Surrounding Environment, M.Sc. thesis, Institute of Environmental Studies and Research, Ain Shams University, Egypt.

El Tablawi, E.M.S. (2010), Study Of The Groundwater Movement With Salt Water Intrusion Using The Mathematical Modeling In El Sheikh Zowied-Rafah, North Sinai, Journal of Geology, Assiut Univ., 38(I), 17.

Giorgi, F.; Jones, C. \& Asrar, G.R. (2009), Addressing climate information needs at the regional level: the CORDEX framework, WMO, Bulletin.

Graham, L. P., J. Andréasson, and B. Carlsson (2007), Assessing climate change impacts on hydrology from an ensemble of regional climate models, model scales and linking methods-A case study on the Lule River basin, Clim. Change, 81(S1), 293-307.

Harris, I.; Jones, P.D.; Osborn, T.J. \& Lister, D.H. (2013), Updated highresolution grids of monthly climatic observations- the CRU TS3.10 Dataset. Int. J. Climatol. 34, 3, 623-642. 
Haylock, M.; Hofstra, N.; Tank, A. K.; Klok, E.; Jones, P. \& New, M. (2008), A European daily high-resolution gridded data set of surface temperature and precipitation, J. Geophys. Res., 113, D20119, 1-12.

Hazeleger, W.; Wang, X.; Severijns, C.; S,tefa nescu, S.; Bintanja, R.; Sterl, A.; Wyser, K.; Semmler, T.; Yang, S.; van den Hurk, B.; van Noije, T.; van der Linden, E. \& van der Wiel, K. (2011), ECEarth V2: description and validation of a new seamless Earth system prediction model, Climate Dynamics. 39.11: 2611-2629.

Holman, I.P. (2006), Climate change impacts on groundwater rechargeuncertainty, shortcomings, and the way forward? Hydrogeol. J. 14 (5), 637-647.

IPCC, (2007), Climate Change 2007: The physical science basis, Contribution of working group I to the fourth assessment report of the Intergovernmental Panel on Climate Change. Cambridge University Press, Cambridge, p. 996.

The Arab Center for Studies and Arid Zones and Dry Lands (ACSAD) and Desert Research Center (DRC), (1998), The mathematical model for El Sheikh Zowied-Rafah, North Sinai, Egypt", ACSAD. W.S./R123/ Damascus (in Arabic).

Undén, P.; Rontu, L.; Järvinen, H.; Lynch, P.; Calvo, J.; Cats, G.; Cuxart, J.; Eerola, K.; Fortelius, K.; Garcia-Moya, J. A.; Jones, C.; Lenderlink, G.; McDonald, A.; McGrath, R.; Navascues, B.; Nielsen, N. W.; Ødegaard, V.; Rodrigues, E.; Rummukainen, M.; Rõõm, R.; Sattler, K.; Sass, B. H.; Savijärvi, H.; Schreuer, B. W.; Sigg, R.; The, H. \& Tijm, A. (2002), HIRLAM-5 Scientific Documentation. HIRLAM Report, SMHI, SE-601 76 Norrköping, Sweden, 144 pp.

Voldoire, A.; Sanchez-Gomez, E.; Salas y Mélia, D.; Decharme, B.; Cassou, C.; Se'ne'si, S.; Valcke, S.; Beau, I.; Alias, A.; Chevallier, M.; De'que', M.; Deshayes, J.; Douville, H.; Fernandez, E.; Madec, G.; Maisonnave, E.; Moine, M.-P. ; Planton, S.; Saint-Martin, D.; Szopa, S.; Tyteca, S. ; Alkama, R.; Belamari, S.; Braun, A.; Coquart, L. \& Chauvin, F. (2013), The CNRM-CM5.1 global 
climate model: description and basic evaluation, Clim Dyn 40: 2091.

Willmott, C. \& Matsuura, K. (1995), Smart interpolation of annually averaged air temperature in the United States, J. Appl. Meteorol., $34,2577-2586$

Xu, C.; Widén, E. \& Halldin, S. (2005), Modelling hydrological consequences of climate change-progress and challenges, Advances in atmospheric sciences, 22, (6), $789-797$.

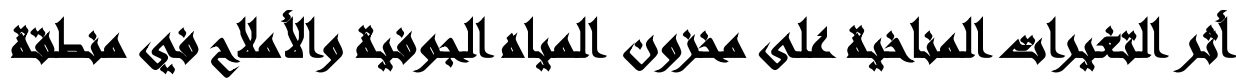

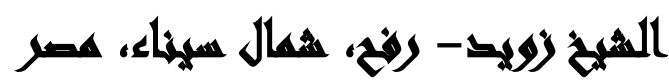

[1]

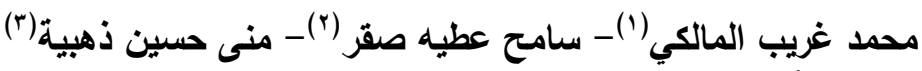

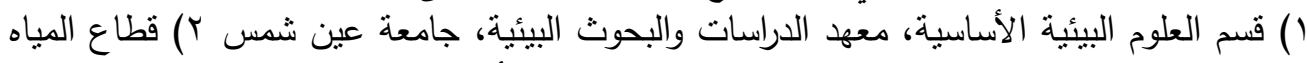
الجوفية، وزارة الموارد المائية والري المصرية الائه معلة سلطة المياه الأردنية

\section{المسرخلص}

إن لدراسة التغيرات المناخية المستقبلية وأثارها على الموارد المياه قيمة اقتصادية واجتماعية

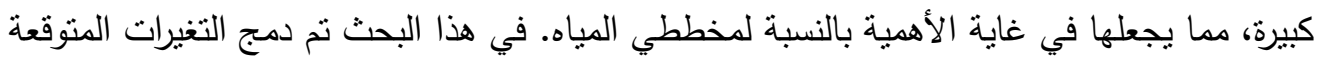

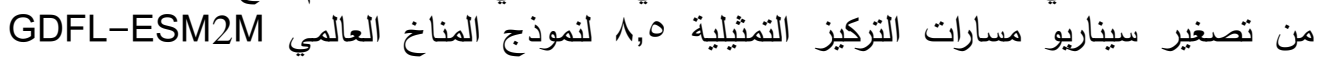

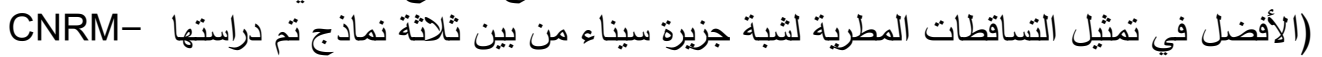
المنات عC-EARTH GFDL-ESM2M CM5

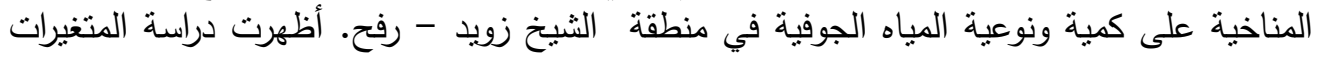

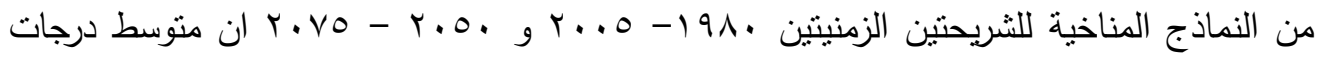

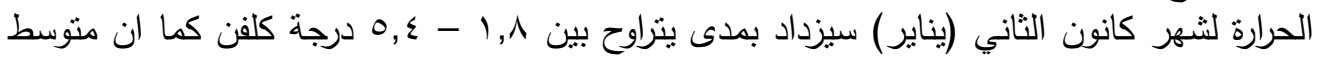

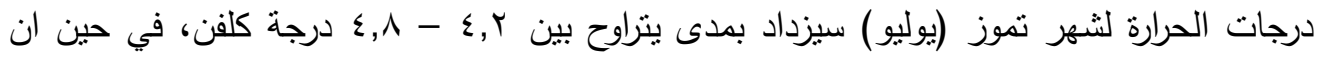

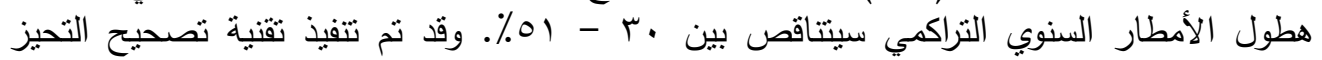

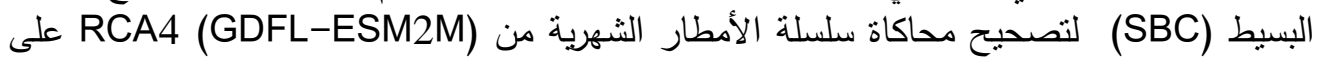

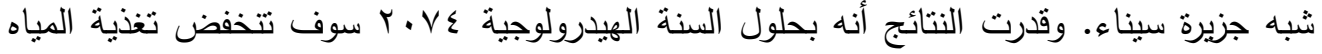

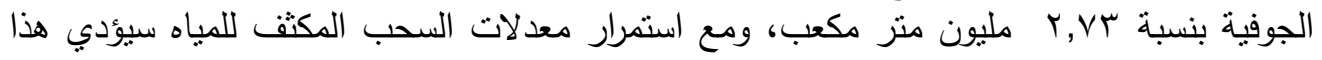


J. Environ. Sci.

Institute of Environmental Studies and Research - Ain Shams University

لخفض مخزون المياه الجوفية إلى بری, ال المليون منز مكعب وهو ما سيترتب عليه تتاقص في كمية

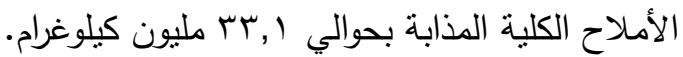

الكلمات الدالة : نماذج المناخ العالمي، نماذجة الماذية المناخ الإقليمية ، نصحيح التحيّز، نموذج تدفق المياه

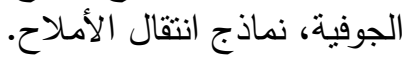

